\title{
CULTURAL TOURISM DEVELOPMENT IN THE TOWN OF BYALA - OPPORTUNITIES FOR INNOVATION
}

\author{
Yoana Konstantinova
}

D.A.Tsenov Academy of Economics, Svishtov, Bulgaria

e-mail:d010422272@uni-svishtov.bg

\section{Received:08 December 2021 Accepted:29 December 2021 Online Published:30 January 2022}

\begin{abstract}
:
This article aims to examine the opportunities for innovations in the development of cultural tourism in the town of Byala. The study focuses on five cultural heritage sites categorized as cultural values of national significance. They are analyzed according to the following three indicators: cultural and historical significance, accessibility, and current condition. The main problems regarding their potential to attract tourists are outlined. For the purpose of the study, several additional factors are considered. They include implemented marketing strategies, established links with travel intermediaries, accommodation and catering establishments.

The main methods used for obtaining the results include the comparative method and the methods of analysis and synthesis. The official sources of information used for the purpose of this study include documents, official websites, and books.

The results of the study indicate that no marketing strategies have been developed and implemented so far and the aforementioned cultural heritage sites remain unknown to potential visitors. No links have been established with travel intermediaries.

On the basis of the analysis carried out, several innovations have been proposed by the author. Due to its rich history and strategic location, the town of Byala has great potential to become a popular destination for cultural tourism.
\end{abstract}

Keywords: cultural tourism, innovations, cultural heritage, cultural heritage site, cultural value, Byala

JEL classification: O10, Z30, Z31

Citation:

Konstantinova, Y. (2022). Cultural tourism development in the town of Byala - opportunities for innovation. Access to science, business, innovation in digital economy, ACCESS Press, 3(1): 67-80.

https://doi.org/10.46656/access.2022.3.1(6)

\section{INTRODUCTION}

Culture is one of the main motivations for tourists to visit a destination. Cultural tourism accounts for about $40 \%$ of all European tourism (European Commission, 2022). According to the definition by the United Nations World Tourism Organization adopted during the $22^{\text {nd }}$ Session of its General Assembly (UNWTO, 2017), cultural tourism is "a type of tourism activity in which the visitor's essential motivation is to learn, discover, experience and consume the tangible and intangible cultural attractions/products in a tourism destination. These attractions/products relate to a set of distinctive material, intellectual, spiritual and emotional features of a society that encompasses arts and architecture, historical and cultural heritage, culinary heritage, literature, music, creative industries and the living cultures with their lifestyles, value systems, beliefs and traditions". Cultural tourism products represent the market value of cultural tourism. Cultural tourism 
development has been identified as one of the priorities in the National Strategy for Sustainable Development of Tourism in the Republic of Bulgaria for the period 2014-2030. According to W. Munsters and G. Richards (Munsters $\S$ Richards, 2021, p. 19), each cultural tourism product is a combination of a core product and additional product. The core product is the cultural tourism supply (museums, monuments, cultural events, etc.) and the related specific cultural tourist services (information and education). The additional product is "the general tourism product elements and the related tourism services that contribute to the tourist attraction value, but that are not in themselves a reason to visit" (Munsters \& Richards, 2021, p.19-20). It consists of general tourism facilities and services transportation infrastructure.

The term "cultural property" is defined in the 1954 Hague Convention for the Protection of Cultural Property in the Event of Armed Conflict as (Convention for the Protection of Cultural Property in the Event of Armed Conflict with Regulations for the Execution of the Convention 1954) "(a) movable or immovable property of great importance to the cultural heritage of every people, such as monuments of architecture, art or history, whether religious or secular; archaeological sites; groups of buildings which, as a whole, are of historical or artistic interest; works of art; manuscripts, books and other objects of artistic, historical or archaeological interest; as well as scientific collections and important collections of books or archives or of reproductions of the property defined above; (b) buildings whose main and effective purpose is to preserve or exhibit the movable cultural property defined in sub-paragraph (a) such as museums, large libraries and depositories of archives, and refuges intended to shelter, in the event of armed conflict, the movable cultural property defined in sub-paragraph (a);(c) centers containing a large amount of cultural property as defined in sub-paragraphs (a) and (b), to be known as 'centers containing monuments",.

According to the Bulgarian Cultural Heritage Act, "Cultural value" is "a non-tangible or tangible evidence of human presence and activity, natural sight or phenomenon, which is significant for the individual, the community or society as a whole, and has value from a scientific or cultural point of view". A cultural value may also be significant for the Bulgarian Orthodox Church'.

"Cultural heritage" is defined by the United Nations Educational, Scientific and Cultural Organization (UNESCO) as "the legacy of physical artifacts and intangible attributes of a group or society that are inherited from past generations, maintained in the present and bestowed for the benefit of future generations" (Sullivan, 2016).

Cultural heritage is further divided into "intangible" and "tangible". Intangible cultural heritage includes "traditions or living expressions inherited from our ancestors and passed on to our descendants" (What Is Intangible Cultural Heritage?, 2021). Tangible cultural heritage includes "the physical objects and artifacts belonging to a culture" such as historic places, buildings, monuments, etc. According to the Bulgarian Cultural Heritage Act, "Cultural value" is "a non-tangible or tangible evidence of human presence and activity, natural sight or phenomenon, which is significant for the individual, the community or society as a whole, and has

\footnotetext{
${ }^{1}$ https://fr.unesco.org/sites/default/files/bulgaria_culturalheritageact_2009_entof.pdf
} 
value from a scientific or cultural point of view". A cultural value may also be significant for the Bulgarian Orthodox Church².

The word innovation comes from the Latin word 'innovationem' (nominative innovatio) meaning 'to change" or "to renew" . There are many definitions of the term ${ }^{4}$. According to one of them, "an innovation is a new or improved product or process (or combination thereof) that differs significantly from the unit's previous products or processes and that has been made available to potential users (product) or brought into use by the unit (process)" ". According to the Oslo Manual, there are four types of innovation: marketing innovation, process innovation, product innovation, and organizational innovation (OECD Library).

Innovations play a key role in the development of cultural tourism. They are aimed at achieving long-term sustainability and profitability. In the context of cultural tourism, the main challenges include attracting more tourists, and preserving cultural resources.

\section{OPPORTUNITIES FOR TOURISM DEVELOPMENT IN THE TOWN OF BYALA}

\section{A. THE TOWN OF BYALA - MAIN FACTORS FOR TOURISM DEVELOPMENT}

The town of Byala is located in Northern Bulgaria. It is the administrative center of Byala Municipality which is the second largest municipality by population in district of Ruse (Fig. 1).

\section{POPULATION IN RUSE DISTRICT BY MUNICIPALITIES IN 2020}

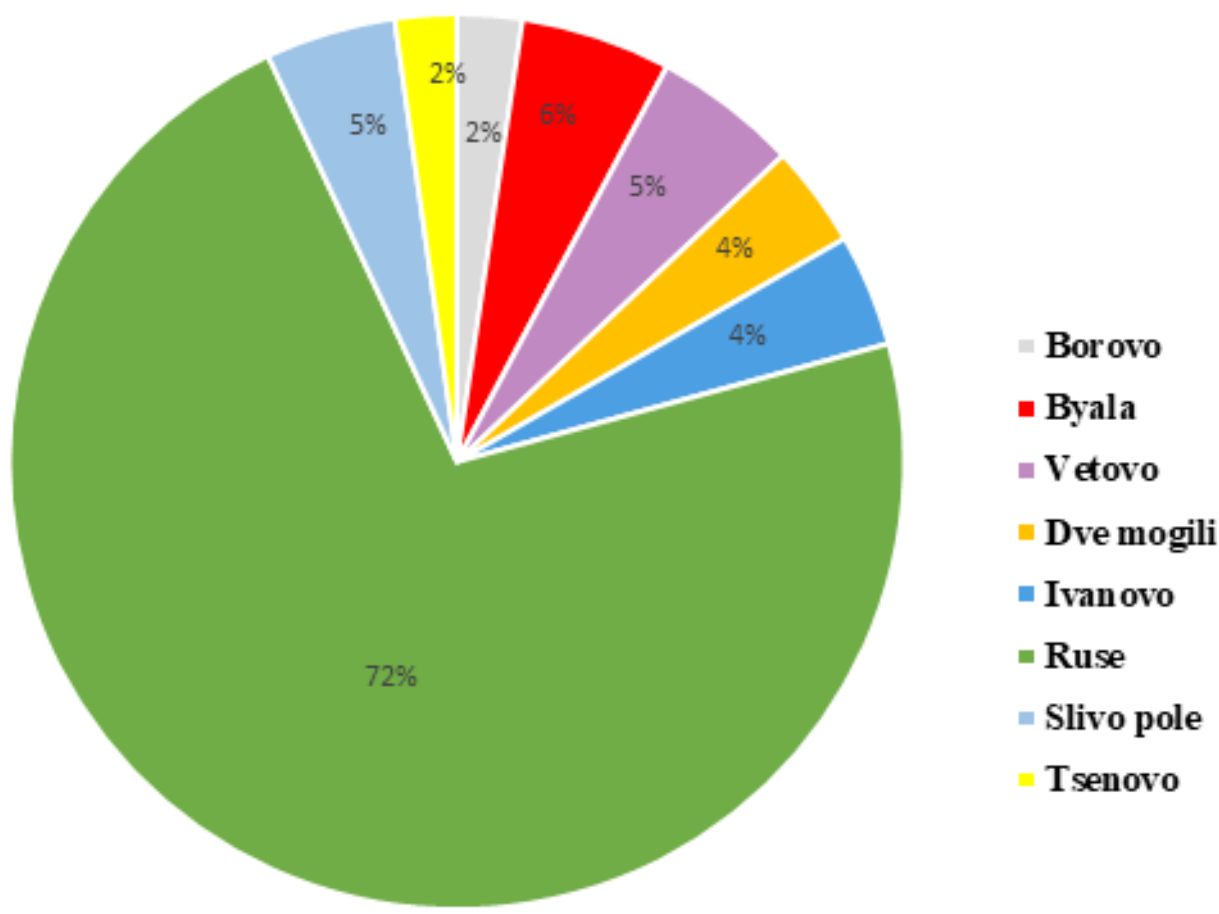

Figure 1. Population in the District of Ruse by Municipalities in 2020

Source: Author's own calculations according to data of the National Statistical Institute

\footnotetext{
${ }^{2}$ https://fr.unesco.org/sites/default/files/bulgaria_culturalheritageact_2009_entof.pdf

${ }^{3} \mathrm{https}: / / \mathrm{www} . e t y m o n l i n e . c o m / s e a r c h ? \mathrm{q}=$ innovation\&ref=searchbar_searchhint

${ }^{4}$ https://torkar.github.io/pdfs/jss-edisonNT13.pdf

${ }^{5}$ https://www.oecd-ilibrary.org
} 
Beside Byala, there are 7 more municipalities included in the district of Ruse (Fig.2). The location of the town of Byala is strategic. The European route E85, which is part of the international E-road network, passes through its territory. The population of the town accounts for $62 \%$ of the total population of Byala Municipality (Fig.3). The number of its inhabitants has been decreasing significantly (Fig 4). The town is easily accessible by road and rail. Its territory of the town has been inhabited since antiquity.

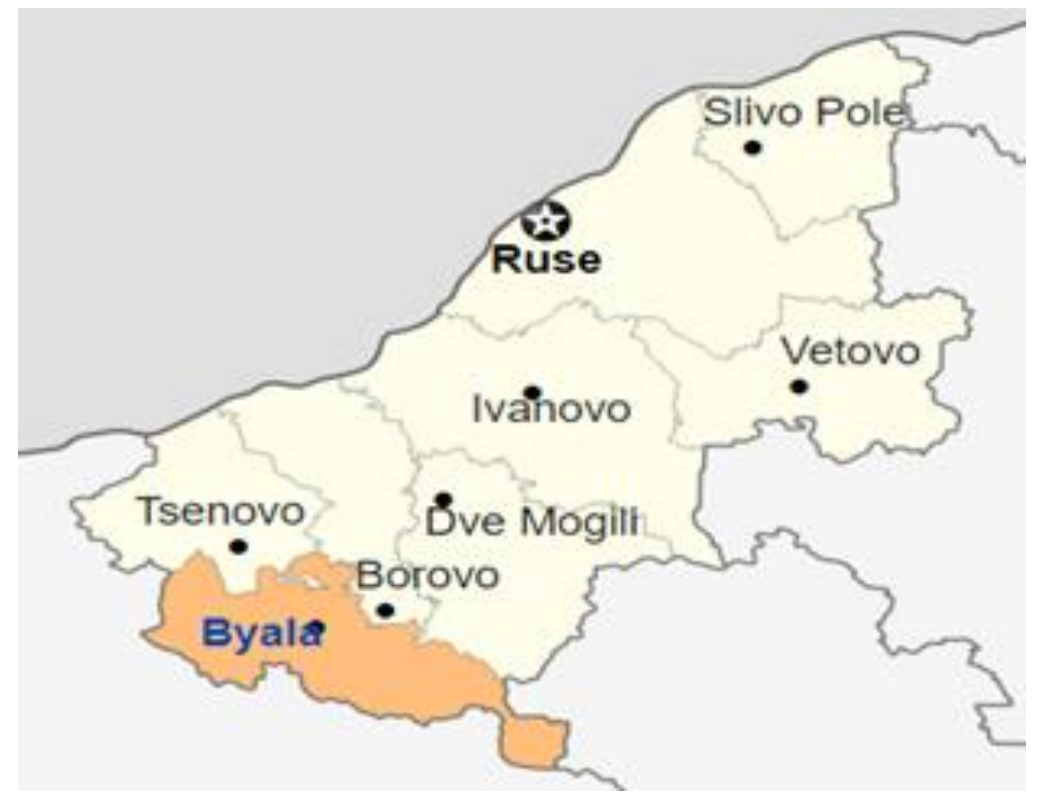

Figure 2. Municipalities in the district of Ruse

Source: https://en.wikipedia.org/wiki/Byala_Municipality,_Ruse_Province

This article aims to examine the opportunities for innovations in the development of cultural tourism in the town of Byala.

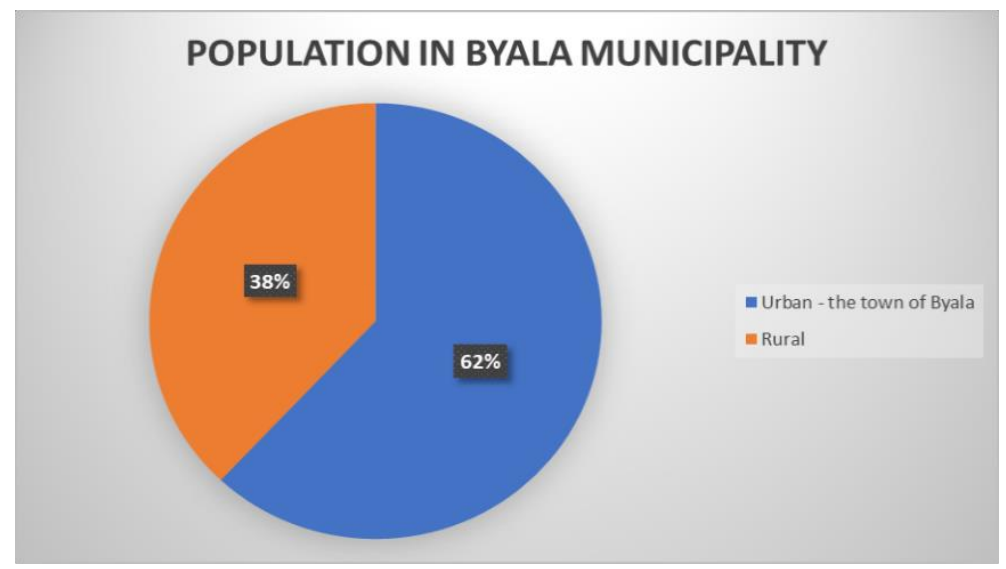

Figure 3. Population in Byala Municipality

Source: The National Statistical Institute 


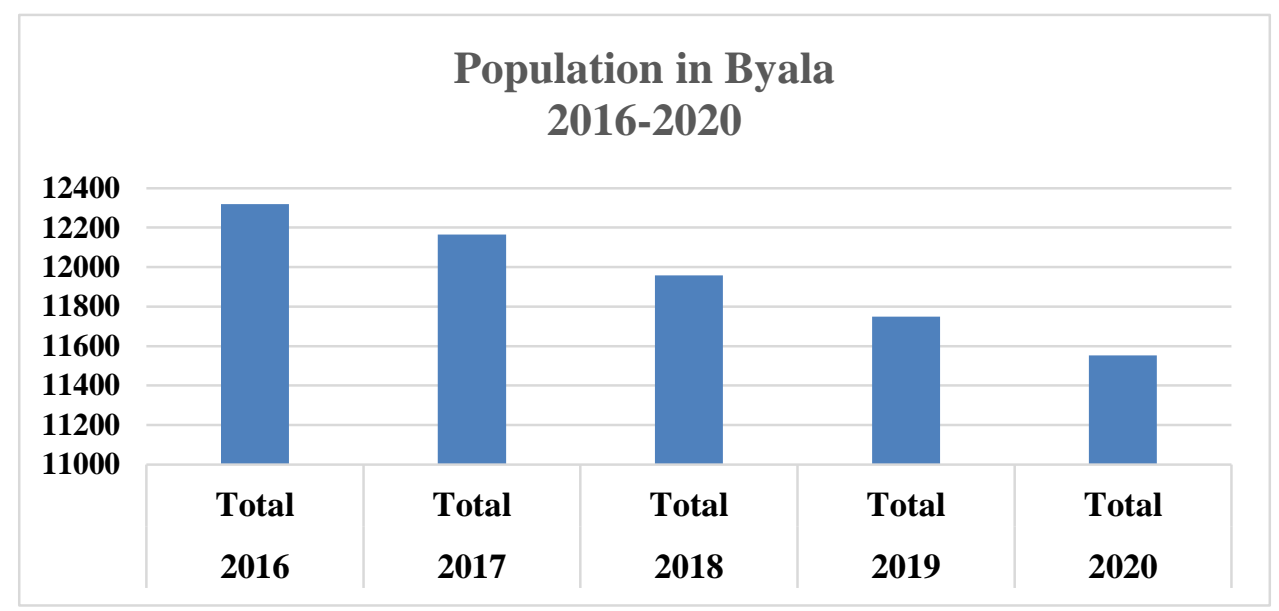

Figure 4. Population in Byala 2016-2020

Source: The National Statistical Institute

The study focuses on five cultural heritage sites categorized as cultural values of national significance. These include Kolyu Ficheto's Bridge over the Yantra River, "St. George" church, the monument of Panayot Volov, Georgi Ikonomov, and Stoyan Angelov, the Liberation War Museum, and the gravestone of Yulia Vrevskaya and Maria Neelova.

\section{B. ACCOMMODATION AND CATERING ESTABLISHMENTS AS AN IMPORTANT FACTOR} CONTRIBUTING TO THE DEVELOPMENT OF TOURISM

There are several accommodation establishments in Byala Municipality. All of them are close to the aforementioned cultural heritage sites. (Table 1).

Table 1. Accommodation establishments in Byala Municipality in 2020

\begin{tabular}{|l|l|l|l|}
\hline \multicolumn{1}{|c|}{ Name } & \multicolumn{1}{|c|}{ Category } & $\begin{array}{c}\text { Number of } \\
\text { stars }\end{array}$ & \multicolumn{1}{c|}{$\begin{array}{c}\text { Number of rooms } \\
\text { and beds }\end{array}$} \\
\hline "Formula 1" & Motel & 1 & 12 rooms; 20 beds \\
\hline "Verona" & Family hotel & 2 & 10 rooms; 22 beds \\
\hline "Odessa" & Family hotel & 1 & 7 rooms; 14 beds \\
\hline "Magnoliya" & Motel & 1 & 8 rooms; 20 beds \\
\hline "Kosharite" & Guest house & 1 & 4 rooms; 8 beds \\
\hline "Mirazh" & Guest rooms & 1 & 4 rooms; 11 beds \\
\hline
\end{tabular}

The restaurant sector contributes significantly to the image of tourist destinations and their cultural heritage sites, respectively (Sparks et al, 2002)

There are 43 catering establishments in Byala Municipality (Table 2). 
Table 2. Catering establishments in Byala Municipality in 2020

\begin{tabular}{|l|c|c|}
\hline \multicolumn{1}{|c|}{ Location } & $\begin{array}{c}\text { Number of catering } \\
\text { establishments }\end{array}$ & Number of seats \\
\hline Byala & 30 & 1867 \\
\hline Bistrentsi & 1 & 20 \\
\hline Bosilkovtsi & 1 & 20 \\
\hline Botrov & 2 & 40 \\
\hline Drianovets & 1 & 20 \\
\hline Koprivets & 3 & 215 \\
\hline Polsko Kosovo & 4 & 145 \\
\hline Peychinovo & 1 & 25 \\
\hline
\end{tabular}

Source: Plan for Integrated Development of Byala Municipality

According to the Plan for Integrated Development of Byala Municipality, the number of overnight stays in the municipality for the period 2017-2019 is 15328 of which 4833 in 2017, 4828 in 2018, and 5667 in 2019. The income from tourist taxes in 2019 is calculated to be BG 3752 .

\section{THE CULTURAL HERITAGE SITES IN BYALA AS A TOOL FOR ATTRACTING TOURISTS}

1. Kolyu Ficheto's Bridge has become a symbol of the town and the municipality of Byala. It is situated about $1 \mathrm{~km}$ from the town of Byala, close to the European route E85, which is part of the international E-road network. The bridge is located near some of the most popular tourist attractions in the region such as the Ivanovo Rock Churches which are included in the UNESCO List, Orlova Chuka cave, the medieval fortified town of Cherven, and the ruins of the Roman and early Byzantine town of Nikopolis ad Istrum.

Kolyu Ficheto's Bridge was built in 1865-1867 by master builder Kolyu Ficheto on the orders of Mithad Pasha, Vali of the Danube Vilayey. Kolyu Ficheto is a Bulgarian builder, architect, and sculptor. AustroHungarian geographer and author of travel notes Felix Kanitz wrote the following about Kolyu Ficheto and the bridge: "This humble man in traditional clothes does not realize that his bridge near Byala is the greatest hydraulic building in the Balkans, excluding Constantinople" (Trankova, 2012).

The bridge is a remarkable achievement of Bulgarian Revival engineering, construction, and architecture. It was declared an architectural monument of art and culture by the National Council for the Protection of Monuments of Culture (Kolyu Ficheto's Bridge over the Yantra River - Byala, n.d.). The bridge is $276 \mathrm{~m}$ long and $9.50 \mathrm{~m}$ wide. It has 14 semicircular arches and 13 pillars. There is a marble slab with an Arabic inscription which is set on one of the pillars in the middle of the bridge. The pillars are decorated with sculptures of symbolic creatures such as swan, griffin, lion, and nymph. In June 1897, several arches in the western part of 
the bridge were destroyed due to a devastating flood. In 1922-1923 the destroyed part of the bridge was restored and reinforced.

\section{The Liberation War Museum}

The exposition reflects events related to the Russo-Turkish Liberation War of 1877-1878. In the yard of the museum, there are original cannons, projectiles, five ten-piece Nobel machine guns, Hertz mines, as well as part of the pontoon bridge on which Russian troops crossed the Danube River. The building is in a typical Bulgarian Revival style. It has 13 rooms.

3. "St George" church was built in 1911. The tower of the church has 4 bells. The largest one weighs 1500 $\mathrm{kg}$.

\section{The gravestone of Yulia Vrevskaya and Maria Neelova}

Yulia Vrevskaya and Maria Neelova were two nurses who worked in one of the field hospitals in Byala during the Russo-Turkish War. Vrevskaya and Neelova got infected with typhus and passed away in early 1878. In 1901, the grave of the nurses was moved to the yard of the Liberation War Museum which is located near the town centre.

\section{The monument of Panayot Volov, Georgi Ikonomov and Stoyan Angelov}

Panayot Volov was one of the leaders and organizers of the Bulgarian April Uprising against the Ottoman Empire in 1876. Together with Georgi Ikonomov, a revolutionary, and Stoyan Angelov, an insurgent, drowned in the Yantra River during their attempt to flee to Romania. They were betrayed to the Ottoman authorities. In 1901 Stoyan Zaimov, Angel Krushkov, and Nikola Obretenov decided to build a monument in their honor.

6. Other cultural heritage sites located in the town of Byala include:

- the Town Clock Tower

- "St. Pantaleon" church

- the Memorial to Nikolay Pirogov

- the Memorial to those killed in the wars in the town of Byala and Ruse Region

- The monument to the Russian officers and soldiers killed in Byala. It is located in Hanishta, one of the districts of the town, near the two bridges over the Yantra River - "The Russian monument"

- The monument of Kolyu Ficheto in the western part of the bridge that was built by him

- Memorials to the volunteers from Byala

- The memorial to the people from Byala and the region who were killed in the wars. It is located in the town center.

- The monument of Diana, the Roman goddess of hunting

\section{METHODS}

The methods used for the purpose of the study include the comparative method and the methods of analysis and synthesis. Comparative analysis is performed with regard to the respective objects of the study. Benchmarking is used for obtaining the results. 
Other methods used for obtaining the results include the collection and organization of information.

The official sources of information used for the purpose of the study include the National Strategy for Sustainable Development of Tourism in the Republic of Bulgaria for the period 2014-2030, the Plan for Integrated Development of the Municipality of Byala for the period 2021-2027, the National Register of Immovable Cultural Heritage, the National Statistical Institute, and the official website of the United Nations World Tourism Organization.

The information used in this study is present in publicly available materials. It includes data collected from websites and books.

\section{RESULTS}

There are five cultural values of national significance on the territory of the district of Ruse (Source: the list of immovable cultural values /ICV/ /monuments of culture/, categorized as "of national significance" on the territory of the district of Ruse, in accordance with the Cultural Heritage Act). All of them are located in the town of Byala. Kolyu Ficheto's bridge is an architectural monument of art and culture.

Kolyu Ficheto's Bridge is currently in poor condition. There are many cracks. The foundations of the bridge are being undermined. The Plan for integrated development of the municipality of Byala for the period 2021-2027 describes a proposed project for the restoration of the bridge and its positioning as a tourist attraction. According to the project, a two-storey building with a modern architectural design is planned to be built close to the bridge (fig.5). The project includes the construction of:

- a restaurant;

- several service rooms;

- a projection hall;

- a souvenir shop.

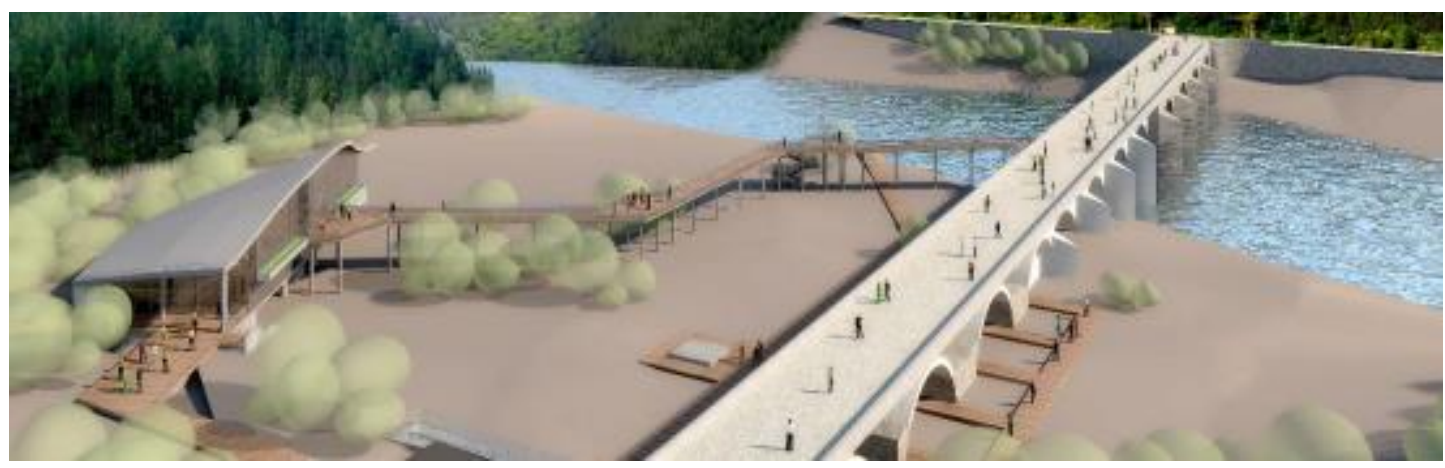

Figure 5. 3D model of Kolyu Ficheto's bridge and the building Source: The Plan for integrated development of the municipality of Byala for the period 2021-2027

Currently, no fees are being collected for the visit of the bridge and no income is being generated. The bridge remains unknown to potential visitors from Bulgaria and abroad. 
The Liberation War Museum in the town of Byala has been declared a cultural value of national significance. The building was erected in the early 19th century. In the early 20th century, it was renovated and turned into a museum. The fence of the museum is made of stone, constructed in the style of a medieval fortress. The museum is located near the town centre and is currently in good condition.

C. "St George" church is currently in good condition. The church is a cultural value of national significance. It is located in the town center and is easily accessible.

D. The gravestone of Yulia Vrevskaya and Maria Neelova is a cultural value of national significance.

The place is easily accessible by road.

E. The monument of Panayot Volov, Georgi Ikonomov and Stoyan Angelov is a cultural value of national significance. The monument is in good condition and easily accessible by road.

Both culture and tourism are essential components of the development of cultural tourism. There are many factors contributing to the development of cultural tourism. Each of them could be an important indicator when analyzing cultural heritage sites and their potential to become popular tourist attractions. The author divides the indicators into three groups (Fig.6). The first group includes three basic indicators, the second group includes the ones related to the promotion of cultural heritage sites, and the third group includes other indicators considered important. The more criteria are fulfilled, the more attractive a cultural heritage site is for tourists. The indicators from the first and the second group are used for the purpose of the study.
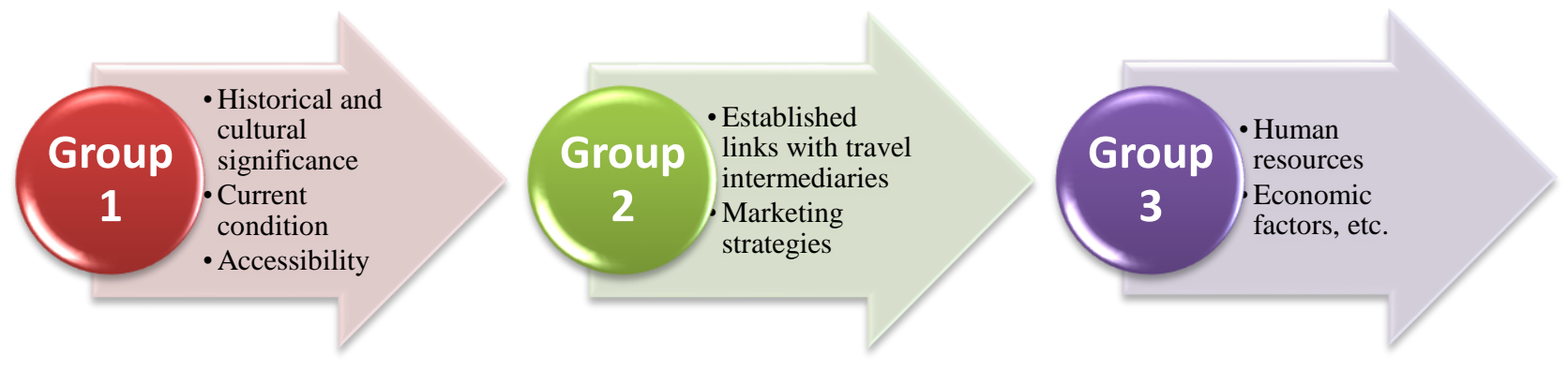

Figure 6. Division of indicators into three groups

In Table 3 a comparative analysis of the cultural heritage sites has been performed in accordance with the author's division of the indicators in group 1 .

The result of the analysis of the cultural heritage sites shows that none of the criteria mentioned in the second group are fulfilled.

The indicators from the third group are subject to further analysis. 
Table 3. Basic indicators, characterizing the cultural heritage sites

\begin{tabular}{|c|c|c|c|}
\hline \multirow[t]{2}{*}{ Name } & \multicolumn{3}{|c|}{ INDICATORS GROUP 1} \\
\hline & $\begin{array}{l}\text { Cultural and } \\
\text { historical significance }\end{array}$ & Accessibility & Current condition \\
\hline Kolyu Ficheto's Bridge & $\begin{array}{l}\text { Cultural value of national } \\
\text { significance. } \\
\text { Architectural monument } \\
\text { of art and culture }\end{array}$ & $\begin{array}{l}\text { Easily accessible by road. } \\
\text { Strategic location, close to the } \\
\text { European route E85 which is } \\
\text { part of the international E-road } \\
\text { network }\end{array}$ & $\begin{array}{l}\text { Currently in bad } \\
\text { condition, } \\
\text { reconstruction }\end{array}$ \\
\hline $\begin{array}{l}\text { The Liberation War } \\
\text { Museum }\end{array}$ & $\begin{array}{l}\text { Cultural value of national } \\
\text { significance }\end{array}$ & $\begin{array}{l}\text { Easily accessible by road. Close } \\
\text { to the town centre; }\end{array}$ & In good condition \\
\hline "St George" church & $\begin{array}{l}\text { Cultural value of national } \\
\text { significance }\end{array}$ & $\begin{array}{l}\text { Easily accessible by road. } \\
\text { Located in the town centre }\end{array}$ & In good condition \\
\hline $\begin{array}{l}\text { The gravestone of } \\
\text { Yulia Vrevskaya and } \\
\text { Maria Neelova }\end{array}$ & $\begin{array}{l}\text { Cultural value of national } \\
\text { significance }\end{array}$ & $\begin{array}{l}\text { Easily accessible by road. Close } \\
\text { to the town centre }\end{array}$ & In good condition \\
\hline $\begin{array}{l}\text { The monument of } \\
\text { Panayot Volov, Georgi } \\
\text { Ikonomov and Stoyan } \\
\text { Angelov }\end{array}$ & $\begin{array}{l}\text { Cultural value of national } \\
\text { significance }\end{array}$ & $\begin{array}{l}\text { Easily accessible by road. } \\
\text { Strategic location, } \\
\text { close to the European route E85 } \\
\text { which is part of the international } \\
\text { E-road network }\end{array}$ & In good condition \\
\hline
\end{tabular}

Source: Systematized by the author

\section{DISCUSSION}

A cultural heritage site should be easily accessible in order to be considered appealing to cultural tourists. All cultural heritage sites in the town of Byala are easily accessible by road.

No links have been established with travel intermediaries such as travel agents and tour operators so far. The total number of tourist agents and tour operators on the territory of the district of Ruse is $57^{6}$. There are no tourist information centers, tourist agents and tour operators located in Byala Municipality (according to the List of Registered Tour Operators and Tour Agents, published on the official website of the Ministry of Economy, Energy and Tourism)

According to the electronic portal of the Ministry of Economy, Energy and Tourism ${ }^{7}$, there are 53 tour operators and tour agents on the territory of the district of Ruse.

\footnotetext{
${ }^{6}$ https://ntr.tourism.government.bg/Registration.nsf/alltato.xsp

${ }^{7}$ http://tourism.egov.bg/registers/TORegister.aspx?AspxAutoDetectCookieSupport=1
} 
There is no official tourism website of the destination. The names of the cultural heritage sites were entered by the author into two of the most popular search engines - Google and Yahoo. The results showed that there is little information available online.

\section{GENERAL CONCLUSIONS:}

- No marketing strategies have been developed and implemented so far. As a result, the cultural heritage sites in the town of Byala remain unpopular;

- In terms of signage and parking facilities, there are not enough tourist signposts and parking places in the town;

- No links with tour operators and tour agents have been established so far

- There is no official tourist website of the tourist destination

- There is no information regarding the cultural heritage sites on social media

- There is not enough information regarding the aforementioned cultural heritage sites on the official website of Byala Municipality

The town of Byala has great potential to become a popular tourist destination, but there is a wide range of problems that require timely and adequate measures.

The measures should be taken in collaboration with the following shareholders:

- The Government (the Ministry of Economy, the Ministry of Tourism)

- The local government (the municipality, the municipal council)

- The regional administration

- The regional and local organizations

- NGOs

- Professional organizations and associations

- SMEs

On the basis of the analysis carried out, several innovations have been proposed by the author. The measures include:

$>$ creating cultural and natural corridors along the Yantra River

$>$ restoration of cultural heritage, if necessary;

$>$ reducing the negative impact of tourism activities such as environmental pollution, destruction of cultural resources, etc.

$>$ establishing links with travel intermediaries such as tour operators and travel agents;

$>$ launching an image campaign;

$>$ setting up partnerships involving all shareholders (government, associations, universities, residents, entrepreneurs, etc.);

$>$ designing an official tourism website of the destination;

$>$ promoting the destination on social media; 
using Big Data in processing information;

using virtual and augmented reality

\section{CONCLUSION}

The analysis performed in the article shows that the main reason for the unpopularity of the cultural heritage sites in the town is the lack of marketing strategies. No links have been established with tour operators and travel agents so far. The strategic approach should be focused mainly on building the desired image of the destination and its cultural heritage respectively. Due to its strategic location and cultural value, the town of Byala has the potential to become a popular tourist destination.

The results from the study could be used for different purposes such as: creating and maintaining a database of cultural heritage in Bulgaria, incorporating strategies for cultural tourism development in the region, performing analysis, and conducting further research on cultural heritage sites in the town of Byala.

\section{Conflict of interests}

The authors declare no conflict of interest.

\section{References}

Architectural heritage of grand master Kolyo Ficheto. (2018). History and Religion. Retrieved January 17, 2022, from https://bnr.bg/en/post/100977787/architectural-heritage-of-grand-master-kolyo-ficheto

Beverley Sparks, Karen Wildman, John Bowen. (2015). Research Report. https://sustain.pata.org/wpcontent/uploads/2015/02/ConsumerInterviews_v5.pdf

Bozhinova, M., Georgieva, K. Organizations for tourism region management in Bulgaria - trends and challenges. Trakia journal of sciences: Series Social sciences, 2019, бp.1, c.365-370, Trakia University, ISSN 1313-7069

Byala keeps the memory of Yulia Vrevska (2013, March 3) [Byala pazi spomena za Yulia Vrevska. (2013, Mart 3)]. Bulevard.bg. Retrieved January 19, 2022, from https://bulevard.bg/news/byala-pazi-spomena-za-yuliya-vrevska$\underline{8470 . \mathrm{html}}$

Benchmarking // A dictionary of business. - Oxford: Oxford University Press, 2002. - P. 112-113

Camp R.C. (1989) Benchmarking. The Search for Indystry Best Practices That Lead to Superior Performance, ASQC Industry Press, Milwaukee, Wisconsin.

Camp R. A. (1993) A bible for benchmarking, by Xerox / R. Camp// Financial Executive.- Vol. 9, No4. - P. 23-29.

Chernyshova, O. (2016). The Female Face of War. The Sisters of mercy during the Russo-Ottoman War of 1877 - 1878 , 3 (XXV), 42-50. Balcanistic Forum. Retrieved January 07, from http://memoryrow.weebly. com/uploads/1/3/8/5/13852932/angelova_kelbecheva_-_gender_and_war_memory_1877-78.pdf

Convention for the Protection of Cultural Property in the Event of Armed Conflict with Regulations for the Execution of the Convention. (n.d.). United Nations Educational, Scientific and Cultural Organization. Retrieved January 17, 2022, from http://portal.unesco.org/en/ev.php-

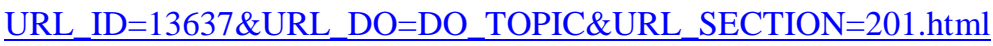

European Comission. (n.d.). Internal Market, Industry, Entrepreneurship and SMEs. Retrieved January 07, 2022, from https://ec.europa.eu/growth/sectors/tourism/offer/cultural_en

European route E85. (2022, January 17). In Wikipedia. https://en.wikipedia.org/wiki/European_route E85

Evans J.R., Lindsay W.M. (2002) The management and control of quality. -5 ed. -Ohio: South Western. -838 p.10

Grayson C. J., O’Dell, C. (1998). If only we know what we know: identification and transfer of internal best practices. 
California Management Review. - 1998. - Vol. 40. - P. 154-174.

History and Culture (n.d.) Byala Municipality. Retrieved from https://byala.bg/bg/1555930017.html

Historical Museum - Byala, Ruse province. (n.d.). EN [Institut za prilozhna muzeologiya]. Retrieved January 07, 2022, from http://www.museology.bg/en/museums/i132/historical-museum-byala.html\#.YdrpOTNBzIU

Hristov , H . (2006). Byala. Short History, pp.10-58, Vesta Pres:Byala // Hristov. H.(2006). Byala. Kratka istoriya, 1058.

Kolarov, I. (1996). Paths to Byala // Kolarov, I. (1996). Pateki kam Byala, pp.46-53.

Kolyu Ficheto's Bridge over the Yantra River - Byala. (n.d.). Bulgaria. A Discovery to Share. Retrieved January 07, 2022, from https://bulgariatravel.org/kolyu-fichetos-bridge-over-the-yantra-river-byala/

List of immovable cultural values /ICV/ /monuments of culture/, categorized as "of national significance" on the territory of the district of Ruse, according to the Cultural Heritage Act., http://ninkn.bg/documents/download/51

List of Registered Tour Operators and Tour Agents http://tourism.egov.bg/registers/TORegister.aspx? $\underline{\text { AspxAutoDetectCookieSupport }=1}$

List of Registered Tourist Associations. https://ntr.tourism.government.bg/TUnionsV2.nsf/tunion.xsp

Ministry of Economy. (2014). Strategy for Sustainable Development of Tourism in Bulgaria 2014-2030 //Strategiya za ustoychivo razvitie na turizma v Bulgaria 2014-2030 [2014-2030] https:/www.tourism.government.bg/sites/ tourism.government.bg/files/uploads/strategy-policy/strategy_2014-2030_13_05_2014-sled_ms_26_05_2014.pdf

Municipality of Byala. (2020). [Plan za integrirano razvitie na obshtina Byala, oblast Ruse za period 2021-2027g.] https://strategy.bg/FileHandler.ashx?fileId=27254

Municipality of Byala. (2020). Plan for Integrated Development of Byala Municipality, Ruse Region for the period 20212027 [Plan za integrirano razvitie na obshtina Byala, oblast Ruse za period 2021-2027g.] https://strategy.bg/FileHandler.ashx?fileId=27254

Municipality of Byala. (2021, February 24). Mowlem.Eu. Retrieved January 07, 2022, from https://mowlem.eu/municipality-of-byala/

Munsters, W., Richards, G. (2021). The Study of Cultural Tourism in Ten Models. 20-21 https://www.researchgate.net/publication/351746481_The_Study_of_Cultural_Tourism_in_Ten_Models__Wil_Munsters

OECD library. The Innovation Imperative Contributing to Productivity, Growth and Well-Being. https://read.oecdilibrary.org/science-and-technology/the-innovation-imperative_9789264239814-en\#page4

Public Register of the National Institute for Immovable Cultural Heritage http://ninkn.bg/documents/download/51

Ruseva, D. (2002). Byala. An Attempt at an Ethnographic Essay //Ruseva, D.(2002). Byala. Opit za etnografski ocherk, 7-9.

Sardak, S. E., Krupskyi, O. P., Dzhyndzhoian, V., Sardak, M., \& Naboka, Y. (2020). Development of historical and cultural tourist destinations. Journal of Geology, Geography and Geoecology, 29(2), $406-414$. https://doi.org/10.15421/112036

Society for Human Resource Management // Glossary, 2005.

Trankova, D. (2012). Major landmark just off international highway near Ruse. Retrieved from January 07 , https://vagabond.bg/bridge-byala-1556

United Nations Educational, Scientific and Cultural Organization. (n.d.). What is Intangible Cultural Heritage? Retrieved January 02, 2022, from https://repository.law.uic.edu/cgi/viewcontent.cgi?article=1392\&context=ripl; https://ich.unesco.org/en/what-is-intangible-heritage-00003

UNWTO. (n.d.). Tourism and Culture. Retrieved January 07, 2022, from https://www.unwto.org/tourism-and-culture

Yasin M. M. (2002) The theory and practice of benchmarking: then and now. Benchmarking: an International Journal. - Vol. 9, No3. - P. 217-243, c.220

http://100nto.org/objects-po-oblasti/rusenska-oblast/50g-biala-muzej.html

http://www.ruskipametnici.com/?action=news\&id=7

$\underline{\text { https://artcenterbyala.bg/ }}$

https://ntr.tourism.government.bg/Registration.nsf/detail.xsp?id=ECDBB1F57BD2F0ACC22576C1002DC9FE 
About the author:

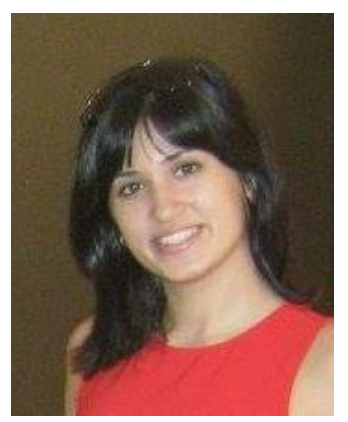

\section{Yoana KONSTANTINOVA}

PhD student, Department of Tourism Economics and Management, Faculty of Industry and Commerce, D.A.Tsenov Academy of Economics, Svishtov, Bulgaria Senior Data Analyst, A Data Pro Ltd: Sofia, Bulgaria

Scientific interests: innovation activities, cultural tourism, innovations, cultural heritage, cultural heritage site, cultural property.

ORCID ID: https://orcid.org/0000-0002-6060-6288

Copyright (C) 2020 by author(s) and ACCESS Publishing Press This work is licensed under the Creative Commons Attribution International License (CC BY) 